\section{Optimizing Plant Density and Production Systems to Maximize Yield of Greenhouse-grown 'Trust' Tomatoes}

\author{
Susannah Amundson ${ }^{1}$, Dennis E. Deyton ${ }^{1}$, Dean A. Kopsell ${ }^{1}$, \\ Walt Hitch ${ }^{2}$, Ann Moore ${ }^{2}$, and Carl E. Sams ${ }^{1,3}$
}

\begin{abstract}
AdDitionAL INDEX wORDs. Solanum lycopersicum, plant spacing, fruit size
\end{abstract}
Summary. Plant spacing and production systems are important factors for maximizing production of greenhouse-grown tomatoes (Solanum lycopersicum). Two studies were conducted simultaneously and independently, each in a $33 \times 96-\mathrm{ft}$ greenhouse in Fall 2008 and Spring 2009 using perlite soilless bag culture. The purpose of the first study was to evaluate yield and fruit weight of 'Trust' tomatoes spaced $12,16,20,24$, or 28 inches in-row. The second study was conducted to determine the effect of pruning production systems on yield and fruit weight. The first system is pruning two plants per bag each to a single leader and the second is pruning one plant per bag to double leader. A plant spacing of 28 inches resulted in significantly more fruit per plant than the 12 -inch plant spacing. However, yield per area decreased with wider plant spacings. Plants spaced 12 inches apart in-row produced 2.8 and $3.8 \mathrm{lb} / \mathrm{ft}^{2}$ total yield in the fall and spring, respectively, compared with plants spaced 28 inches apart that produced 1.7 and $2.2 \mathrm{lb} / \mathrm{ft}^{2}$ in the fall and spring. Using a production system with one plant per bag pruned to a double leader increased yield by $6.4 \mathrm{lb} /$ plant in the fall and $15.7 \mathrm{lb} /$ plant in the spring. On a per bag basis, pruning two tomato plants to one leader increased total yield by $2.6 \mathrm{lb} /$ bag and was more economical in the fall; whereas, in the spring, the double leader production system did not affect yield but was more economical.

$\mathrm{I}$ n 2003, U.S. greenhouse growers produced $\approx 175,996$ tons of tomatoes; however, imports still exceeded domestic production, with 282,323 tons from Canada and Mexico alone (Cook and Calvin, 2005). This factor provides opportunities for growers to increase U.S. greenhouse tomato production. As of 2003 , large ( $>40$ acres) and medium (7-40 acres) operations accounted for $62 \%$ and $15 \%$, respectively, of total U.S. greenhouse tomato productivity (Cook and Calvin, 2005). Over time, the largest U.S. greenhouse firms have shifted locations to align production with the most profitable market windows and use the warmer winter climates while simultaneously targeting the high-priced winter season (Cook and Calvin, 2005). Although this shift allows profitable production all yearlong, it also increased transportation expenses. This, according to Hanna (2009), accounts for a substantial part of tomato production expenses and

${ }^{1}$ Department of Plant Sciences, University of Tennessee, 2431 Joe Johnson Drive, Knoxville, TN 37996

${ }^{2}$ Plateau Research and Education Center, University of Tennessee, 320 Experiment Station Road, Crossville, TN 38571

${ }^{3}$ Corresponding author. E-mail: carlsams@utk.edu. usually mandates growers to cut costs, increase yield, or both.

Small greenhouse tomato operations are still prevalent in the United States and focus mainly on local sales on the premises or to farmer's markets and retailers (Cook and Calvin, 2005; Korevaar, 2007). In order for these small family farms to compete in the market, they must either tap into a niche market, such as heirlooms or cherry tomatoes, or reduce production costs and increase plant yield (Korevaar, 2007; Hanna, 2009). In short, despite the size of operation or location, growers are always pursuing ways to increase yield.

Greenhouse tomato production requires many environmental, cultural, and biological practices to optimize production and fruit quality. Plant density and pruning methods are two important cultural approaches to increase yield. It has been recommended by Snyder (2007) and the Louisiana State University AgCenter (2009) that each tomato plant should receive 4$4.3-\mathrm{ft}^{2}$ growing area, with about a 13.7-15.7-inch spacing between plants and $4 \mathrm{ft}$ between rows. Previous tomato studies, grown in both field and greenhouse conditions, have demonstrated various responses to plant density. With greenhouse-grown cherry tomato, Charlo et al. (2007) found that increasing plant spacing from 11.8 to 19.7 inches resulted in greater yield per plant but lowered productivity per unit area, while decreasing plant density resulted in greater yield per area but smaller more nonmarketable fruit. Similarly, Saglam and Yazgan (1995) reported that tomatoes grown in unheated greenhouses had overall yield per unit area increase with an increased density. Kemble et al. (1994) found no yield differences between in-row spacing of 12 and 30 inches in field-grown tomato. However, Santos et al. (2010) determined that higher yields of field-grown tomatoes were obtained by using smaller in-row spacing.

Franco et al. (2009) stated that choosing a proper pruning system was important to keep a balance in the relationship's source/sink and the carbon/nitrogen $(\mathrm{C} / \mathrm{N})$ ratio. There are several reports that confirm the benefits of pruning on tomato yields. Cockshull et al. (2001) found a tendency for side shoots to reduce the yield of marketable fruit produced on each cluster in greenhouse production.

Pruning needs differ depending on the growth habit of the cultivar, but typically it is recommended that

\begin{tabular}{llll}
\hline $\begin{array}{l}\text { Units } \\
\begin{array}{l}\text { To convert U.S. to SI, } \\
\text { multiply by }\end{array}\end{array}$ & U.S. unit & SI unit & $\begin{array}{l}\text { To convert SI to U.S., } \\
\text { multiply by }\end{array}$ \\
\hline 0.4047 & $\mathrm{acre}(\mathrm{s})$ & $\mathrm{ha}$ & 2.4711 \\
0.3048 & $\mathrm{ft}$ & $\mathrm{m}$ & 3.2808 \\
0.0929 & $\mathrm{ft}^{2}$ & $\mathrm{~m}^{2}$ & 10.7639 \\
3.7854 & $\mathrm{gal}$ & $\mathrm{L}$ & 0.2642 \\
2.54 & inch(es) & $\mathrm{cm}$ & 0.3937 \\
0.4536 & $\mathrm{lb}$ & $\mathrm{kg}$ & 2.2046 \\
4.8824 & $\mathrm{lb} / \mathrm{ft}^{2}$ & $\mathrm{~kg} \cdot \mathrm{m}^{-2}$ & 0.2048 \\
1 & $\mathrm{ppm}$ & $\mathrm{mg} \cdot \mathrm{L}^{-1}$ & 1 \\
0.9072 & $\mathrm{ton}(\mathrm{s})$ & $\mathrm{Mg}$ & 1.1023 \\
$\left({ }^{\circ} \mathrm{F}-32\right) \div 1.8$ & ${ }^{\circ} \mathrm{F}$ & ${ }^{\circ} \mathrm{C}$ & $\left(1.8 \times{ }^{\circ} \mathrm{C}\right)+32$ \\
& & &
\end{tabular}


indeterminate greenhouse tomato plants be pruned to one stem by removing all side shoots (Snyder, 2007). However, literature indicates that productivity per unit area increases when pruning tomato plants to two stems. Aung (1999) reported that greater marketable yield per unit area was obtained by pruning indeterminate field tomatoes to two stems rather than one stem. Borisoy et al. (1978) found that greenhouse tomato yield per unit area increased $10 \%$ to $15 \%$ when pruned to two stems rather than one. Common pruning studies compare one plant with one leader and one plant with two leaders. This study was designed to compare two production systems, one using one plant per grow bag pruned to a double leader, the other using two plants per grow bag each pruned to single leaders. Growers are exploring ways to decrease production costs by cutting back on the number of transplants needed by using one plant with two leaders per 5 -gal grow bag instead of two plants with one leader per grow bag. However, there is not adequate data to support the yield benefits and possible cost savings to support this practice. The objective of this study was to evaluate different plant densities and pruning production systems to maximize yield and fruit size for indeterminate tomatoes grown hydroponically under greenhouse conditions.

\section{Materials and methods}

Two studies were conducted simultaneously and independently in Fall 2008 and Spring 2009 at the University of Tennessee Plateau Research and Education Center in Crossville, TN (lat. $\left.35^{\circ} 56^{\prime} \mathrm{N}\right)$. Each study was performed in a $33 \times 96-\mathrm{ft}$ double layer polyethylene covered greenhouse using 'Trust' tomato (DeRuiter Seeds, Columbus, OH). Tomatoes were seeded into plastic germination trays filled with soilless germination mix composed of peatmoss, perlite, and vermiculite (BM2; Berger Peat Moss, Saint-Modeste, QC, Canada) on 27 June 2008 for fall crop and 26 Dec. 2008 for spring crop. Ten days later, seedlings were transplanted into 38cell plastic trays containing all-purpose soilless mix composed of peatmoss, perlite, vermiculite, and starter fertilizer (BMl, Berger Peat Moss). Transplants were grown for $\approx 6$ weeks before transplanting at the fourth to fifth true leaf stage into white 3 -gal (spacing study) or 5-gal (pruning study) grow bags containing perlite. Fall transplanting occurred on 22 Aug. 2008, and spring transplanting occurred on 7 Feb. 2009. Fall temperatures averaged $83 / 62^{\circ} \mathrm{F}$ (day/night). Spring temperatures averaged $85 / 64{ }^{\circ} \mathrm{F}$ (day/night).

The first study was designed to evaluate the effect of plant spacing on yield. One plant was transplanted into each 3-gal bag and spaced on-center according to its designated treatment. A row spacing of $4 \mathrm{ft}$ remained constant, and different plant densities were achieved by varying in-row spacing. Treatments were as follows: 12 , $16,20,24$, and 28 inches $(0.11,0.25$, $0.19,0.16,0.13$, and 0.11 plants $/ \mathrm{ft}^{2}$, respectively). The experiment was arranged in a randomized complete block design with three replications of five treatments and 20 plants per experimental unit. The experimental layout consisted of five double rows (18 inches apart on-center) spanning the length of the greenhouse with north/south orientation. The center three rows were the experimental rows and the outer two rows were borders. Plants were pruned to a single leader. Simple linear regression was used to study changes in fruit yield associated with increases in plant spacing by partitioning the sums of squares into components that were associated with linear terms with SAS (version 9.2; SAS Institute, Cary, NC).

The second study compared production systems: two plants with one leader and one plant with two leaders. Depending on the treatment, either one or two plants were transplanted into 5 -gal bags, which were spaced 18 inches on-center in rows $5 \mathrm{ft}$ apart. The experiment was designed as a randomized complete block with four replications of two treatments and five bags per experimental unit, equaling five plants per experimental unit for the two leader treatment and 10 plants per experimental unit for the one leader. The two treatments consisted of either one plant per bag pruned to a double leader or two plants per bag pruned to a single leader each. For single leaders, all suckers were removed. For double leaders, the sucker just below the first flower cluster was left to remain as the second leader. Yield data were analyzed using analysis of variance mixed models with SAS (version 9.2; SAS Institute, Cary, NC). Blocks, or replications, were considered random, and treatments were considered fixed. Significance of main effects was determined by $\mathrm{F}$ test.

For both experiments, plants were clipped to a string supported by an overhead wire and grown to the 10th flower cluster before being topped. Flower clusters were thinned to four or five fruit per cluster to remove excess fruit and flowers and to optimize fruit size. Pollination was accomplished by bumblebees [Bombus impatiens (Koppert Biological Systems, Romulus, $\mathrm{MI})]$. The fertilizer solution made up of $3 \mathrm{~N}-5.7 \mathrm{P}-24.1 \mathrm{~K}$ (Tomato Special; TotalGro, Winnsboro, LA), magnesium sulfate $\left[\mathrm{Mg}\left(\mathrm{SO}_{4}\right)_{2}\right]$, potassium nitrate $\left(\mathrm{KNO}_{3}\right)$, calcium nitrate $\left[\mathrm{Ca}\left(\mathrm{NO}_{3}\right)_{2}\right]$, and calcium chloride $(\mathrm{CaCl})$ at a $100 \%$ strength supplied nutrients in the following concentrations (in $\mathrm{mg} \cdot \mathrm{L}^{-1}$ ): 190 nitrogen, 50 phosphorus, 324 potassium, 187 calcium, 65 magnesium, and 3 iron. The fertilizer schedule followed recommendations based on Snyder (2007). Fall harvest began on 3 Nov. 2008 and ended on 20 Jan. 2009. Spring harvest began on 20 Apr. 2009 and ended on 2 July 2009. Tomatoes from each treatment/replication were harvested at the pink stage once per week for 12 weeks. Unmarketable fruit (culls or small fruit) were discarded, and the remaining fruit were graded based on diameter as follows: jumbo ( $>3.0$ inches), extra large (2.75-3.0 inches), large (2.5-2.75 inches), and medium (2.25-2.5 inches) (U.S. Department of Agriculture, 2007). Weight and number of fruit in each grade were recorded for each treatment/replication, and total marketable yield was determined by combining all grades.

\section{Results and discussion}

Expт. 1. Plant spacing affected greenhouse tomato total yield, yield of jumbo-size fruit, and average fruit weight per plant as well as per area (Tables 1 and 2). A positive linear trend showed that total yield/plant, jumbo yield/plant, and fruit weight increased with every increased increment in spacing. The highest 'Trust' yield of jumbo fruits produced per plant were obtained by an in-row spacing treatment of 28 inches in both seasons. In the fall, plants at 28-inch spacing produced $4.5 \mathrm{lb}$ more jumbos per plant than those spaced 12 inches 
Table 1. Regression analysis of fruit size and yield per plant and per unit area of greenhouse 'Trust' tomato fruit grown in double rows spaced 18 inches $(45.7 \mathrm{~cm})$ on-center with $4 \mathrm{ft}(1.2 \mathrm{~m})$ between rows. Different plant densities were achieved with various in-row spacing treatments in Fall 2008.

\begin{tabular}{|c|c|c|c|c|c|c|}
\hline \multirow{2}{*}{$\begin{array}{l}\text { Plant } \\
\text { spacing } \\
\text { (inches) }^{z}\end{array}$} & \multirow{2}{*}{$\begin{array}{c}\text { Plant } \\
\text { spacing } \\
\left(\text { plants } / \mathrm{ft}^{2}\right)^{\mathrm{z}}\end{array}$} & \multicolumn{2}{|c|}{$\begin{array}{l}\text { Fruit yield } \\
(\mathrm{lb} / \text { plant })^{\mathrm{z}}\end{array}$} & \multicolumn{2}{|c|}{$\begin{array}{c}\text { Fruit yield } \\
\left(\mathrm{lb} / \mathrm{ft}^{2}\right)^{\mathrm{z}}\end{array}$} & \multirow{2}{*}{$\begin{array}{c}\text { Mean } \\
\text { fruit } \\
\text { wt (lb) }\end{array}$} \\
\hline & & Jumbo $^{y}$ & Total & Jumbo & Total & \\
\hline 12 & 0.25 & 7.0 & 11.1 & 1.7 & 2.8 & 0.48 \\
\hline 16 & 0.19 & 8.7 & 12.6 & 1.6 & 2.4 & 0.52 \\
\hline 20 & 0.16 & 9.6 & 13.4 & 1.5 & 2.1 & 0.54 \\
\hline 24 & 0.13 & 10.9 & 14.6 & 1.4 & 1.8 & 0.57 \\
\hline 28 & 0.11 & 11.5 & 15.4 & 1.2 & 1.7 & 0.57 \\
\hline
\end{tabular}

Linear $^{x}$

$<0.0001$

0.0005

$0.0006<0.0001$

$<0.0001$

${ }^{\mathrm{z}} \mathrm{l}$ inch $=2.54 \mathrm{~cm}, \mathrm{l}$ plant $/ \mathrm{ft}^{2}=10.7639$ plants $/ \mathrm{m}^{2}, \mathrm{l} \mathrm{lb}=0.4536 \mathrm{~kg}, \mathrm{l} \mathrm{lb} / \mathrm{ft}^{2}=4.8824 \mathrm{~kg} \cdot \mathrm{m}^{-2}$

yumbo is categorized as any tomato $>3.0$ inches diameter.

${ }^{x}$ Fruit yield in response to plant spacings described as the following linear regression equations: jumbo/plant: $y=$ $3.89+0.28 x$; total $/$ plant: $y=8.09+0.27 x$; jumbo $/ \mathrm{ft}^{2}: y=2.14-0.03 x ;$ total $/ \mathrm{ft}^{2}: y=3.53-0.07 x$; fruit weight: $y=0.29+0.02 x$.

Table 2. Regression analysis of fruit size and yield per plant and per area of greenhouse 'Trust' tomato fruit grown in double rows spaced 18 inches $(45.7 \mathrm{~cm})$ on-center with $4 \mathrm{ft}(1.2 \mathrm{~m})$ between rows. Different plant densities were achieved with various in-row spacing treatments in Spring 2009.

\begin{tabular}{|c|c|c|c|c|c|c|}
\hline \multirow{2}{*}{$\begin{array}{l}\text { Plant } \\
\text { spacing } \\
\text { (inches) }^{z}\end{array}$} & \multirow{2}{*}{$\begin{array}{c}\text { Plant } \\
\text { spacing } \\
\left(\text { plants } / \mathrm{ft}^{2}\right)^{\mathrm{z}}\end{array}$} & \multicolumn{2}{|c|}{$\begin{array}{l}\text { Fruit yield } \\
(\mathrm{lb} / \text { plant })^{\mathrm{z}}\end{array}$} & \multicolumn{2}{|c|}{$\begin{array}{c}\text { Fruit yield } \\
\left(\mathrm{lb} / \mathrm{ft}^{2}\right)^{\mathrm{z}}\end{array}$} & \multirow{2}{*}{$\begin{array}{c}\text { Mean } \\
\text { fruit } \\
\text { wt (lb) }\end{array}$} \\
\hline & & Jumboy $^{y}$ & Total & Jumbo & Total & \\
\hline 12 & 0.25 & 9.8 & 15.2 & 2.4 & 3.8 & 0.48 \\
\hline 16 & 0.19 & 12.0 & 17.3 & 2.3 & 3.2 & 0.51 \\
\hline 20 & 0.16 & 14.7 & 18.9 & 2.3 & 3.0 & 0.54 \\
\hline 24 & 0.13 & 16.1 & 19.5 & 2.0 & 2.4 & 0.57 \\
\hline 28 & 0.11 & 16.8 & 20.0 & 1.8 & 2.2 & 0.60 \\
\hline
\end{tabular}

Linear $^{\mathrm{x}}$

$<0.0001$

0.0005

0.01

$<0.0001$

$<0.0001$

${ }^{\mathrm{z}} \mathrm{l}$ inch $=2.54 \mathrm{~cm}, \mathrm{l}$ plant $/ \mathrm{ft}^{2}=10.7639$ plants $/ \mathrm{m}^{2}, \mathrm{l} \mathrm{lb}=0.4536 \mathrm{~kg}, \mathrm{l} \mathrm{lb} / \mathrm{ft}^{2}=4.8824 \mathrm{~kg} \cdot \mathrm{m}^{-2}$

yumbo is categorized as any tomato $>3.0$ inches diameter.

${ }^{x}$ Fruit yield in response to plant spacings described as the following linear regression equations: jumbo/plant: $y=$ $4.7+0.45 x$; total $/$ plant: $y=12.2+0.29 x$ jumbo $/ \mathrm{ft}^{2}: y=2.9-0.037 x$; total $/ \mathrm{ft}^{2}: y=4.9-0.10 x$; fruit weight: $y=$ $0.38+0.009 x$

apart (Table 1 ) and $6.3 \mathrm{lb}$ more jumbos per plant in the spring (Table 2 ). When compared with plants spaced 12 inches apart, a plant spacing of 28 inches resulted in a total yield increase of $4.3 \mathrm{lb} /$ plant in the fall and $4.8 \mathrm{lb} /$ plant in the spring. Wider plant spacing also resulted in increasing the average fruit weight per plant, from $0.48 \mathrm{lb}$ with the 12 -inch spacing treatment to $0.57 \mathrm{lb}$ with the 24 and 28 -inch spacing treatments. In this experiment, increasing in-row spacing by 1 inch linearly increased total yield per plant by $0.27 \mathrm{lb} /$ plant in the fall and $0.29 \mathrm{lb} /$ plant in the spring and increased jumbo fruit yield by $0.28 \mathrm{lb} /$ plant in the fall and $0.45 \mathrm{lb} /$ plant in the spring. Lower plant densities produced more tomatoes per plant; however, with less plants being grown because of larger in-row spacing, total yield per area was lower (Tables 1 and $2)$. There was a negative linear correlation between wider in-row plant spacing and total yield per unit area and jumbo yield per unit area. With every increase in plant spacing, yield per area decreased. Per area, plants in the 12 -inch spacing resulted in a total yield of $2.8 \mathrm{lb} / \mathrm{ft}^{2}$ in the fall and 3.8 $\mathrm{lb} / \mathrm{ft}^{2}$ in the spring, whereas plants in the 28 -inch spacing only yielded 1.7 $\mathrm{lb} / \mathrm{ft}^{2}$ in the fall and $2.2 \mathrm{lb} / \mathrm{ft}^{2}$ in the spring, an increase of $\approx 40 \%$. Similarly, the amount of jumbo tomatoes produced per area increased with closer spacings. The 12 -inch spacing resulted in 1.7 and $2.4 \mathrm{lb} / \mathrm{ft}^{2}$ of jumbo tomatoes in the fall and spring, respectively. The 28 -inch spacing resulted in only 1.2 and $1.8 \mathrm{lb} / \mathrm{ft}^{2}$ in the fall and spring, respectively, equaling a $30 \%$ increase of jumbo yield. Although yield per area increased with the smaller spacing, it is not necessarily desirable for growers since the fruit produced were smaller, $0.48 \mathrm{lb}$ with the 12 -inch spacing compared with 0.57 and 0.60 lb with the 28 -inch spacing (Tables 1 and 2). By increasing in-row plant spacing by 1 inch, overall yield per area decreased linearly by $0.07 \mathrm{lb} / \mathrm{ft}^{2}$ in the fall and $0.10 \mathrm{lb} / \mathrm{ft}^{2}$ in the spring, jumbo yield decreased by $0.03 \mathrm{lb} / \mathrm{ft}^{2}$ in the fall and $0.037 \mathrm{lb} / \mathrm{ft}^{2}$ in the spring, and average fruit weight increased by $0.009 \mathrm{lb}$.

These findings correspond to the findings of Papadopoulos and Ormrod (1990). They found that with a narrow plant spacing, yield per plant declined but yield per area increased. This can be explained by the increased interplant and intraplant competition that is imposed with higher plant densities (Fery and Janick, 1970; Rodriguez and Lambeth, 1975). They also attribute this to the fact that with lower plant densities (wider spacing) there is increased photosynthetically active radiation interception to the plant canopy, specifically the lower basal leaves, resulting in higher carbon dioxide $\left(\mathrm{CO}_{2}\right)$ fixation, which ultimately increases yield per plant and fruit size (Papadopoulos and Ormrod, 1990).

Closer cropping increases yield per area, but decreases yield per plant and fruit weight, while increasing the risk for diseases and pests. High plant densities are best used in situations with high light or where fruit size is not of great concern.

ExPT. 2. In the production systems study, the treatment effect significantly affected yields (Tables 3 and 4 ). The production system of one plant per 5-gal bag pruned to a double leader resulted in more total fruit/ plant and extra large yield/plant than two plants per 5-gal bag pruned to single leaders. The double leader system produced significantly higher total yields during fall and spring seasons, 15.4 and $29.1 \mathrm{lb} /$ plant, respectively, compared with the single leader system with 9 and $13.4 \mathrm{lb} /$ plant during the fall and spring, respectively (Tables 3 and 4 ). The one plant with two leader system produced 6.4 and $15.7 \mathrm{lb}$ more fruit per plant during the fall and spring than two plants with single leaders. Although yield/plant is interesting from a physiological standpoint, it is yield/bag that is most 
pertinent to growers trying to decrease production cost while not sacrificing yield. On a per bag basis, two plants with one leader yielded more fruit for the fall crop, $18 \mathrm{lb} / \mathrm{bag}$ (9 lb/ plant each) compared with $15.4 \mathrm{lb} /$ bag of a single plant with double leaders (Table 3). During the spring crop, the system produced comparable yields (Table 4). So, by using the same floor space, water, and fertilizer, one would have higher yields in the fall by having two plants each with a single leader, as the double leader plant produces $15.5 \mathrm{lb} / \mathrm{bag}$ of tomatoes, and the two single leader plants together produce $18 \mathrm{lb} / \mathrm{bag}$ of tomatoes. However, in the spring, it would be more beneficial to use the double leader system than the single leader system as it decreases input costs of seeds and transplants without reducing yield. Maintenance and labor inputs were equal for both pruning systems, except seeding and planting, theoretically, would take half as much time when using the double leader system. Using the double leader production system would be beneficial if the cost of using twice as many plants (as for the one leader system) outweighs the possible profits achieved by the increased yield. However, a cost analysis (Table 5) calculating the projected gross income for one $3000-\mathrm{ft}^{2}$ house using $4 \mathrm{ft}^{2}$ growing area per grow bag shows that the yield increase of a single leader system outweighs the increased seed cost in the fall but not in the spring. Estimates show an increase in profit of $\$ 2925.00$ by pruning two plants per bag to a single leader in the fall, whereas in the spring, the opposite holds true, pruning one plant per bag to a double leader will be $\$ 2587.50$ more profitable. A disadvantage of the double leader production system is that when diseases, such as Botrytis cinerea, are present, there is a greater chance of losing the whole plant, whereas if there are two plants per bag, it may affect one plant but not the other. This factor may partly explain why the single leader system was more effective in the fall when greenhouse disease pressure is greatest in Tennessee.

\section{Conclusions}

An in-row spacing of 16-20 inches (18 inches being ideal) is recommended for 'Trust' tomato growers wanting to maximize greenhouse space without negatively affecting yield or fruit weight. A production system that

Table 3. Yield of greenhouse 'Trust' tomato grown in two production systems: two plants per bag with one leader each or one plant per bag with two leaders in Fall 2008.

\begin{tabular}{|c|c|c|c|c|c|c|}
\hline \multirow[b]{2}{*}{ Treatment } & \multicolumn{3}{|c|}{ Fruit yield $(\mathrm{lb} / \text { plant })^{\mathrm{z}}$} & \multicolumn{3}{|c|}{ Fruit yield $\left(\mathrm{lb} / \mathrm{ft}^{2}\right)^{\mathrm{z}}$} \\
\hline & Extra large $^{y}$ & Jumbo $^{y}$ & Total & Extra large & Jumbo & Total \\
\hline $\begin{array}{l}1 \text { leader, } 2 \\
\text { plants /bag }\end{array}$ & $1.9 b^{x}$ & $5.7 \mathrm{a}$ & $9.0 \mathrm{~b}$ & $4.0 \mathrm{a}$ & $11.5 \mathrm{a}$ & $18.0 \mathrm{a}$ \\
\hline $\begin{array}{l}2 \text { leaders, } 1 \\
\text { plant/bag }\end{array}$ & $4.1 \mathrm{a}$ & $7.8 \mathrm{a}$ & $15.4 \mathrm{a}$ & $4.1 \mathrm{a}$ & $7.8 \mathrm{~b}$ & $15.4 \mathrm{~b}$ \\
\hline$P$ value & 0.002 & $\mathrm{NS}^{\mathrm{w}}$ & 0.0003 & NS & 0.025 & 0.02 \\
\hline
\end{tabular}

Table 4. Yield of greenhouse 'Trust' tomato grown in two production systems: two plants per bag with one leader each or one plant per bag with two leaders in Spring 2009.

\begin{tabular}{|c|c|c|c|c|c|c|}
\hline \multirow[b]{2}{*}{ Treatment } & \multicolumn{3}{|c|}{ Fruit yield $(\mathrm{lb} / \text { plant })^{\mathrm{z}}$} & \multicolumn{3}{|c|}{ Fruit yield $\left(\mathrm{lb} / \mathrm{ft}^{2}\right)^{\mathrm{z}}$} \\
\hline & Extra large ${ }^{y}$ & Jumbo $^{y}$ & Total & Extra large & Jumbo & Total \\
\hline $\begin{array}{l}1 \text { leader, } 2 \\
\text { plants /bag }\end{array}$ & $2.5 b^{x}$ & $10.1 \mathrm{a}$ & $13.4 \mathrm{~b}$ & $6.4 \mathrm{a}$ & $20.3 \mathrm{a}$ & $26.8 \mathrm{a}$ \\
\hline $\begin{array}{l}2 \text { leaders, } 1 \\
\text { plant/bag }\end{array}$ & $6.4 \mathrm{a}$ & $21.0 \mathrm{a}$ & $29.1 \mathrm{a}$ & $5.0 \mathrm{a}$ & $21.0 \mathrm{a}$ & $29.1 \mathrm{a}$ \\
\hline$P$ value & 0.016 & $\mathrm{NS}^{\mathrm{w}}$ & 0.05 & NS & NS & NS \\
\hline
\end{tabular}

Table 5. Cost analysis of single leader vs. double leader training systems in one $3000-\mathrm{ft}^{2}\left(278.7 \mathrm{~m}^{2}\right)$ greenhouse using $4-\mathrm{ft}^{2}\left(0.37 \mathrm{~m}^{2}\right)$ growing area per grow bag for 'Trust' tomato.

\begin{tabular}{|c|c|c|c|c|c|c|}
\hline Treatment & $\begin{array}{c}\text { Transplant } \\
\text { costs }^{\mathrm{z}}\end{array}$ & $\begin{array}{c}\text { Fall } \\
\text { yield }(\mathrm{lb})^{\mathrm{y}}\end{array}$ & $\begin{array}{c}\text { Spring } \\
\text { yield (lb) }\end{array}$ & $\begin{array}{c}\text { Tomato } \\
\text { price } \\
(\$ / 1 b)^{y}\end{array}$ & $\begin{array}{c}\text { Fall } \\
\text { gross } \\
\text { income }(\$)\end{array}$ & $\begin{array}{c}\text { Spring } \\
\text { gross } \\
\text { income }(\$)\end{array}$ \\
\hline $\begin{array}{l}1 \text { leader, } \\
2 \text { plants }\end{array}$ & $\$ 750$ & 13,500 & 20,100 & $\$ 1.50$ & 20,250 & 30,150 \\
\hline $\begin{array}{l}2 \text { leaders, } \\
1 \text { plant }\end{array}$ & $\$ 375$ & 11,550 & 21,825 & $\$ 1.50$ & 17,325 & 32,737 \\
\hline
\end{tabular}

prunes two plants per bag each to a single leader is most profitable in the fall, whereas, in the spring, it is more profitable to prune one plant per bag to a double leader.

\section{Literature cited}

Aung, M. 1999. Effect of pruning and spacing on performance of fresh market tomato. AVRDC 1-7. AVRDC-The World Vegetable Center, Bangkok, Thailand.

Borisoy, V.Y., R.L. Borisova, and V.T. Belik. 1978. The dependence of tomato yield on spacing and plant training. Puti Povysheniya Urozhainosti Plodov i Ovoshchnykh Kul'tur 54-59.

Charlo, H.C.O., R. Castoldi, L.A. Ito, C. Fernandes, and L.T. Braz. 2007. Productivity of cherry tomatoes under protected cultivation carried out with different types of pruning and spacing. Acta Hort. 761:323-326.

Cockshull, K.E., L.C. Ho, and J.S. Fenlon. 2001. The effect of the time of taking shoots on the regulation of fruit size in glasshouse-grown tomato crops. J. Hort. Sci. Biotechnol. 76:474-483. 


\section{Research Reports}

Cook, R. and L. Calvin. 2005. Greenhouse Tomatoes Change the Dynamics of the North American Fresh Tomato Industry. 4 Mar. 2011. <http://postharvest.ucdavis. edu/datastorefiles/234-447.pdf>.

Fery, R. and J. Janick. 1970. Response of the tomato to population pressure. J. Amer. Soc. Hort. Sci. 95:614-624.

Franco, J.L., N. Rodriguez, M. Diaz, and F. Camacho. 2009. Influence of different pruning methods in cherry tomato grown hydroponically in a cropping spring cycle: Effects on the production and quality. Acta Hort. 843:165-169.

Hanna, H.Y. 2009. Influence of cultivar, growing media, and cluster pruning on greenhouse tomato yield and fruit quality. HortTechnology 19:395-399.

Kemble, J.M., J.M. Davis, R.G. Gardner, and D.C. Sanders. 1994. Spacing, root cell volume, and age affect production and economics of compact-growth-habit tomato. HortScience 29:1460-1464.

Korevaar, S. 2007. Greenhouse market in the USA. Practical Hydroponic Greenhouses 93(2):34-35.

Louisiana State University AgCenter. 2009. Greenhouse Tomato Production Handbook. 11 June 2011. <http://www. lsuagcenter.com/NR/rdonlyres/38D013C6A7BF-4702-88DC-921E038778F8/ 10111/HannaTomatoBook.pdf>.

Papadopoulos, A. and D. Ormrod. 1990. Plant spacing effects on yield of the greenhouse tomato. Can. J. Plant Sci. 70:565-573.

Rodriguez, B. and V. Lambeth. 1975. Artificial lighting and spacing as photosynthetic and yield factors in winter greenhouse tomato culture. J. Amer. Soc. Hort. Sci. 100:694-697.
Saglam, N. and A. Yazgan. 1995. The effect of planting density and the number of trusses per plant on earliness, yield and quantity of tomato grown under unheated high plastic tunnel. Acta Hort. 412:258-267.

Santos, B.M., J. Scott, and M. RamirezSanchez. 2010. In-row distances and nitrogen fertilization programs for 'TastiLee' specialty tomato. HortTechnology 20:579-584.

Snyder, R.G. 2007. Greenhouse Tomato Handbook. Mississippi State Ext. Ser. Bul. P1828. 18 Oct. 2011. <http://msucares. com/pubs/publications/p1828.htm $>$.

U.S. Department of Agriculture. 2007. United States Standards for Grades of Greenhouse Tomatoes. 4 Mar. 2011. <http:// www.ams.usda.gov/AMSv1.0/getfile? dDocName=STELPRDC5050332> 